\title{
Policy Enabling Environment of Mining Sector in Tanzania: A Review of Opportunities and Challenges
}

\author{
Willy Maliganya $^{1} \&$ Kenneth M. K. Bengesi ${ }^{1}$ \\ ${ }^{1}$ Department of Policy Planning and Management, College of Social Sciences and Humanities, Sokoine \\ University of Agriculture, Morogoro, Tanzania \\ Correspondence: Willy Maliganya, Department of Policy Planning and Management, P.O.Box 3035 Chuo Kikuu, \\ Morogoro, Tanzania. Tel: 255-754-864-540. E-mail: wmaliganya@yahoo.com
}

Received: December 15, 2017 Accepted: June 12, $2018 \quad$ Online Published: July 23, 2018

doi:10.5539/jsd.v11n4p1

URL: https://doi.org/10.5539/jsd.v11n4p1

\begin{abstract}
Mining has increasingly become an important contributor to the economy of developing countries including Tanzania. Since independence, Tanzania has made several efforts in response to address the challenges in the mining sector to enhance its contribution to the national economy. However, such efforts have not been successful in addressing the persisting challenges, which includes lack of expected benefits, failure to develop policy options for making the investment environment supportive for all actors in the sector; hence failure to use mineral wealth sustainably. The reasons for the persistence of these challenges are not well documented especially in relation to the policy framework. While some scholars attribute these challenges to bad deals with mining companies, others blame the government for its failure to effectively implement, monitor and enforce the existing regulatory framework. This paper reviews the policy enabling environment of the mining sector in Tanzania. The results indicate that Tanzania has taken measures to create some opportunities through policy enabling environment. However, the measures have not been able to achieve the expected results due to the persistence of targeted challenges in the sector. In view of this, improvement of the policy framework is particularly needed where policy gaps have accelerated for poor practices.
\end{abstract}

Keywords: investment incentives, land policy; mining policy; mining Sector, regulatory framework

\section{Introduction}

Mining is one among important sectors of the economy particularly in many developing countries including Tanzania. It is also one of the areas where environmental concerns have frequently been voiced (Pedro, 2012; Darimani, 2009). However, one of the key challenges has been to develop policy options for making investments in the mining sector which are supportive to all actors for sustainable development. While it has been difficult for the mining sector in most African countries endowed with mineral resources to contribute to sustainable development, preliminary evidence suggests that under appropriate and effective legal framework, investments in mining might have higher economic returns (Cambell, 2010).

Literature shows further that the richness in terms of mineral resources in Africa has definitely raised hope for the attainment of socio-economic development among the people especially to those who are in areas where such resources are being extracted (Kabange, 2013). This is particularly possible when such resources are exploited sustainably (African Mining Vision (AMV, 2009). However, the presence of mineral resources has so far not been able to contribute significantly on the well-being of the wider society (Kronenberg, 2004; Mikesell, 1998; Auty, 1993).

In view of the above, a lot of complaints have been frequently raised especially from communities adjacent to mineral resources due to little benefits accrued but carrying the burden of the negative environmental and social costs (Magai \& Marquez, 2011; Kahyarara, 2015). Concerns have also emerged that issues pertaining to land acquisition and resettlements of communities affected by large scale mining operation are not adequately been addressed in terms of providing fair and timely compensation (Lugoe, 2012; 2013; Kitula, 2006). However, with effective governance, exploitation of mineral resources is likely to contribute significantly towards sustainable development (Jeschke, 2010; Lederman \& Maloney, 2007; Ferranti et al., 2002).

While other countries such as Botswana, Namibia have been demonstrated as role models in terms of utilization 
of mineral resources for boosting the well-being of their economies and thus the people, the situation is different in other African countries including Tanzania (Leveille, 2009). Although Tanzania is one of the countries blessed with a huge reserve of mineral resources, its level of development does not reflect the level of available natural resources in terms of minerals, oil and gas (URT, 2011; 2013). As a result of this failure to effectively exploit these resources, incidences of poverty level are widely evident especially in areas where such resources are being extracted (URT, 2013; Lange, 2011; Lugoe, 2012).

Although Tanzania has, since 1980s, embarked on comprehensive social and economic reforms aimed at improving the policy and legal frameworks with respect to mineral resources management, there is still evidence of inadequacies of such policies (Kahyarara, 2015). While the Tanzania mining policy of 2009 aimed among other things to promote sustainable exploitation and development of mining activities through enhanced local content and improved artisanal and small scale miners for poverty reduction among the majority in the country, the practical experience on the ground towards achieving these policy objectives has remained a challenge to the time of writing this paper.

Additionally, the ongoing public debates on whether the state receives a fair share from the mining sector deals are one of the indicators necessitated the need to conduct this review. For example, of late, there have been more discoveries of the country's resource deposits such as natural gas which have the potential to significantly contribute to the economic growth and development thereby supporting the diversification of the economy into high value adding activities and thus, improve the living standards of citizens in Tanzania. Nevertheless, this has remained a critical challenge in terms of realizing this potential due to weak linkages between mining activities and the local economies (Kahyarara, 2015; Muganyizi, 2012; Lugoe, 2012). Since this linkage is missing, the management of wealth from the extractive sector has recently raised more concerns following its recent disappointing results towards achieving sustainable development.

While there has been a number of research efforts in response to addressing the existing challenges in the mining sector (Maliganya \& Renatus, 2017; Lange \& Kinyondo, 2016; Kabote \& Niboye, 2013; Lange, 2011), most of them have covered little on issues related to the policy enabling environment in the mining sector. Whereas some of these studies have tried to focus on the general contribution of the sector to socio-economic development and environmental protection in the country, little is known specifically on the opportunities and challenges in respect to local content, land acquisition, artisanal and small-scale miners as among the persisting policy challenges in the sector; the experience of the regulatory environment in other context benefiting from mining sector and whether there are any lessons learned from other context. With this happening in the mining sector, this situation has raised concerns which necessitated the need to conduct this study to analyze whether there was a favourable policy enabling environment in the Tanzania mining sector.

In this regard, this paper responds to the following questions; what are the opportunities and challenges in the mining sector enabling environment in Tanzania? What is the experience of the regulatory environment in other context benefiting from the mining sector? Are there any lessons learned from other context that can be extrapolated to Tanzania? Thus, this paper makes a useful contribution in demonstrating how the regulatory framework could contribute towards sustainable management of the mining sector and promote equitable benefit sharing. Since Tanzania is currently undergoing through a serious policy and legal reforms in the sector, this paper is timely as it will provide policy options on the best practice to contribute to the process. Therefore, the rest of the paper is organized into the following sections. In the first part, the paper presents the methodology used for this review. Section two provides an analysis of the major findings for the paper and the last section gives the conclusions and policy recommendations in response to addressing the challenges identified in this review.

\section{Methodology}

This paper involved desk review of various documents such as books, journal articles, electronic sources, policy documents and legislations. It was essentially based on evaluating relevant literature on legal and regulatory framework with regards to the mining sector in Tanzania. The analysis has been done in relation to the perspectives of how the policy environment plays an important role in the governance of the mining sector in Tanzania. In view of this, systematic review method of literature was used for policies and legislation from Tanzania and best practices elsewhere in order to capture needed information. Therefore, the paper confined itself to secondary sources of information on the basis of qualitative data. The review also utilized documented experiences on the best practices from successful countries that are richly endowed with mineral resources such as Australia, Botswana, Namibia, South Africa, Ghana and others of the kind by identifying key gaps in the policy framework (Wilcox, 2015). 


\section{Results and Discussion}

This paper attempts to answer four research questions as follows; what are the opportunities and challenges in the mining sector enabling environment in Tanzania? What is the experience of the regulatory environment in other context benefiting from the mining sector? Are there any lessons learned from other context that can be extrapolated to Tanzania? In its subsequent sections, the paper provides a critical review of existing opportunities and challenges in an enabling environment of mining sector in Tanzania, explores best practices in the regulatory environment from others contexts and draw lessons from best practices which form bases for recommendations on how best the Tanzania government can improve the existing regulatory framework.

\subsection{Opportunities in the Mining Sector}

While the development of Tanzania mining sector depends partly on the extent to which challenges facing the sector will be addressed, it is also important to understand the existing opportunities in order to allow the government to create an enabling environment to support investment initiatives in the sector. Therefore, this section attempts to highlight issues such as political stability of the country and abundant natural resource base, investment incentives, existence of the legal framework and the role of bilateral investment treaties to ensure secure investment environment.

\subsubsection{Political Stability of the Country and Abundant Natural Resource Base}

Political stability is a predictable political environment, which in turn attracts investment, both internally and from outside (Bengesi, 2018). For investors to decide on a location for investments, a number of factors are considered including the political stability of a given country and the available resource base (Kinda, 2010; James, 2010). According to Bengesi (2018) political instability affects growth because it increases policy uncertainty, which has negative effects on productive economic decisions such as investment and saving. A high probability of a change of government implies uncertainty in future policies; consequently, the risk-averse economic agents may wait to take productive economic initiatives or might even "exit" the economy by investing abroad. In this case, the uncertainty associated with an unstable political environment may reduce investment and the speed of economic development.

This review indicates that the presence of political stability and abundant natural resources in Tanzania offers a wide range of investors' opportunities. The investment environment in Tanzania has been stable in that the current political environment is deemed conducive for investors. Additionally, this review shows further that the Tanzania's untapped natural resources offer an extensive range of potential investment opportunities. As a result of this, Tanzania has become a destination for potential investors from all over the world given the stability of the political environment (Mbowe et al., 2016).

\subsubsection{Investment Incentives}

The desire to attract and retain more investors has compelled most governments especially in developing nations to make extensive use of investment incentives in efforts to attract investments. Investment incentives in this paper are defined as the inducements offered by the government or local authorities to encourage capital investment by the private sector either generally or in a specific area designed to reduce the risk attached to an investment. Increasingly, this has prompted governments to provide incentives of various kinds to foreign investors in order to attract investments usually in form of foreign direct investment (Jaiswal, 2017; James, 2010).

In Tanzania, the government provides a wide range of investment incentives such as fiscal incentives and regulatory concessions (Bengesi, 2018; URT, 2008; Curtis \& Lissu, 2008; Muganyizi, 2012). These incentives are aimed at attracting and retaining greater levels of FDIs into the country preferably in the mining sector. In respect to the mining sector, mining companies are given various fiscal incentives such as tax holidays, tax reduction and exemptions. Other incentives include individual Mining Development Agreements, which the government has signed with specific companies. Also other incentives offered in respect to the mining sector include zero rated duty on capital goods, spare parts, vehicles and supplies until first production anniversary (Curtis \& Ngowi, 2017; URT, 2016).

While the above are considered as constituting the opportunities to be exploited by both local and foreign investors, the findings of this review indicate that, investment incentives, which target for or give preferential treatment to foreign investors are by nature discriminatory. While much has been written about the desirability of using incentives to attract new investments, empirical evidence on the cost effectiveness of using them to increase investment is inconclusive. As a result, studies have confirmed that such tax incentives are leading to large revenue losses. With tax incentives, this implies that the money that could be collected as taxes is not 
collected. In its extreme case, lack of transparency on the extent of tax incentives has long prevented the public to adequately scrutinize them. Consequently, the beneficiaries of tax incentives and exceptions in Tanzania have been a small group of foreign investors due to substantive losses on part of the government and the general public. This tendency suggests therefore that the disadvantages of tax incentives vastly outweigh the advantages, which is contrary to the intention of the policy objective.

\subsubsection{Incentives in the Regulatory Framework and Bilateral Investment Treaties}

The aim of policies for investments is to provide investors with an environment in which they can conduct their business profitably and without encountering unnecessary risks. One of an important factor to ensure this is the presence of a predictable regulatory environment (Mbowe et al., 2016). In Tanzania, the investment environment is generally regulated under the 1997 Tanzania investment Act, which set up the Tanzania Investment Center (TIC). This investment law provides a one stop shop center through which local and foreign investors can obtain the approvals necessary for the undertaking of investment (URT, 1997). In achieving these, the legal framework provides support to this focus on the private sector through establishing a variety of incentives that could encourage sustainable investments. However, the incentives provided by the framework are sometimes not well coordinated and have resulted in some cases in competing rather than complementing each other. This review indicates that while the law has provided strong foundation on which to facilitate sustainable activities, implementation has proved to be difficult due to ambiguities in the law, weak or absence of implementing the regulations and/or lack of supporting incentives altogether.

On the other hand, bilateral investment protection agreements/treaties (BITs) have as well obtained common usage because countries prefer to negotiate them directly in order to secure preferential treatment for their companies and protect their investments (UNCTAD, 2014; Rutahiwa \& Simwela, 2012). Under Tanzania law, international investment agreements are given superior treatments. Given the fact that Tanzania is an active member of Multilateral Investment Guarantee Agency (MIGA), which recognize the private property and protection against any non-commercial risks, also a member of the International Center for Settlement of investment Disputes (ICSID) that ensure secure investment environment (Curtis \& Ngowi, 2017; URT, 2016). In this view, the policy environment provides an attractive investment climate for both bilateral and multilateral communities to consider Tanzania as an appropriate investment destination.

\subsection{The Challenges in the Mining Sector Enabling Environment}

While Tanzania's mining policy does present some opportunities to be realized, its ability to ensure achievement of the desired outcomes remain limited. There are a number of challenges that still exist in the sector which need attention if the mining sector is to contribute sustainably for the wider society. Therefore, this section seeks to highlight challenges with greater emphasis on aspects related to local content, land acquisition and resettlement as well as on the potential of artisanal and small scale miners.

\subsubsection{The Challenges for Local Content in the Mining Sector}

The use of local content strategies has become more important in recent years due to the need for many government to enhance the contribution of the mining sector to the wider community (Andrews and Nwapi, 2018; White, 2017; Nwapi, 2016; Mpelumbe, 2012). In this regard, local content is increasingly becoming an important component of the government's strategy to ensure that the mining sector substantially contributes to the long term sustainable development. In the context of Tanzania, the mineral policy 2009 lays the foundation for creating an enabling environment to stakeholders and potential investors. For example, "Sections 34(1) (f); $41(4)(\mathrm{g})$ and 49 (2) (h) of the mining Act 2010, requires mining companies to procure locally goods and services and government to support and promote Tanzanians to supply quality goods and services to the mining industry" (URT, 2009). However, to the time of writing this paper, it was not clear how effective were these instruments in terms of addressing the existing challenges since several mining companies still engage in imports of goods and services that could otherwise be sourced within Tanzania.

While Tanzania has recently taken some serious measures to improve its local content policies, in practice this has not been achieved. Although the government has established a local content policy for the nascent oil and gas sector, local content policies in the mining sector is still underdeveloped since there are no specific local content policy/legislation properly governing mining investments. In this way, the country is not that much benefiting as much as it could from foreign investment in this respect.

Despite the fact that the local content provisions are covered in the policy document, it is surprisingly not fully elaborated in the mining Act 2010. This argument has been supported by Shivji (2007a) who argues that the Act does not impose any conditions related to development objectives such as training and employment of 
Tanzanians, sourcing of local goods and services. In light of this, Tanzania's local content policies are considered weak especially in the mining sector since there is lack of plans and strategies for implementation on the ground and mechanisms for monitoring compliance in achieving the targets (Curtis \& Ngowi, 2017).

\subsubsection{The Challenges forLand Acquisition and Resettlement}

"The 1977 constitution of the United Republic of Tanzania is the fundamental law in Tanzania, overriding all other legislation. Article 24 of the constitution guarantees the right to own property and to protect it in accordance with the law (URT, 1997). There is thus, full recognition of private property and protection against any commercial risks. The Tanzania investment Act, No 26 of 1997, under section 22(1) also guarantees mining business as against nationalization or appropriation by providing that no business enterprise shall be nationalized or appropriated by the government. It is further stated under section (2) of the same provision that "there shall not be any acquisition, whether wholly or in part of a business enterprise to which this Act applies by the state unless the acquisition is under the due process of the law which makes provision for payment of fair, adequate and prompt compensation". Indeed, subsection (2) of the same article stipulates clearly that "it shall be unlawful for any person to be deprived of his property without the authority of law which makes provisions for fair and adequate compensation" (URT, 1997).

Despite these legal provisions, land acquisition and ownership has been reported as one of the problematic situation of the mining industry under which land occupier prior mineral discovery losses their land without compensation or inadequately compensated. While land acquisition is legally justifiable in the context of Tanzania, this goes contrary with the right to adequate and prompt compensation to the affected as provided in the provisions of Land Act, No 4 of 1999 and Village Land Act No 5 of 1999. As a result, land laws do not provide adequate protection to rural communities affected by mining operations due to weak tenure rights over the land. This paper argues that land compensation should conform to and not violates the right to own property as granted by article 24 of the constitution of the united republic of Tanzania, 1997.

Previous studies also have shown that there have been cases where unethical government officials and mining companies forcibly remove artisanal and small scale miners as well as local communities to give way for mining operations without providing them with adequate compensation as provided by the law (Bengesi, 2014; Kabote \& Niboye, 2013). Similar practices were reported earlier in biofuel investments in Kisarawe, Lindi and Bagamoyo districts in Tanzania (Bengesi et al., 2009). In most cases, communities who are forced off their land are normally not consulted. Lissu \& Curtis (2008) have demonstrated this in relation to the cases which happened at Bulyanhulu Gold Mining. This suggests that displacement and resettlement programmes are conducted without prior informed consent and some communities finds themselves in worse situations after relocation.

The results imply that there was a mismatch between policy statements, legal provisions and reality on the practical experience on the ground. For example, the regulatory framework does not clearly stipulate the criteria for compensation to those communities affected by large scale mining operations. This suggests that establishment of initiatives to share benefits from mining investments with local communities are a major step towards a comprehensive and systematic approach to address the challenges in mining areas that take into considerations the interests of various stakeholders. Kahyarara (2015) argues that despite increased opportunities available in the mining industry, oil and gas, unless a strategic approach is adopted, Tanzania might not be able to effectively maximize gains from the resources for the benefits of all people. This has been the motive force for the persistent conflicts between local communities and large-scale mining companies and/or investors in the country (Acuna, 2015; Mwakaje, 2013; Akabzaa, 2009; URT, 2008).

Moreover, a study by Ange (2014) shows that in Kenyan constitution, Article 69 urges the state to manage natural resources in an equitable way for the benefit of all Kenyans. However, communities including those in Nguluku have been voicing their concern about the Titanium mining project that has led to loss of land, displacement and environmental degradation.In Botswana, where the mining sector has performed better, the country has relied on enhancing strong institutions that are transparent, participatory, effective and efficient based on the rule of law.

\subsubsection{The Challenges for Artisanal and Small-Scale Miners}

The Artisanal and Small-Scale Miners (ASM) sub-sector is an important source of livelihoods especially in rural areas (Ange, 2014). As a result, efforts to formalize the sector have increasingly become important including registering and organizing unregulated and bring artisanal and small Scale Miners (ASM) into the formal economy (Ange, 2014; URT, 2009). While the Tanzania mineral policy 2009 strongly stresses on the need to set out strategies for rationalizing artisanal and small-scale mining into organized and efficient operations in order to 
ensure gainful employment and poverty reduction, the investment environment for artisanal and small-scale miners has been one of the areas with persistent challenges.

Indeed, the regulatory environment in some incidences have tended to give large scale investors largely operated by foreign firms more avenues to operate in the sector.While Tanzania government has made efforts to establish small scale section under the organization of the Ministry of Energy and Minerals (MEM), there has been lack of clear legal and policy framework to support and facilitate sustainability of ASM in Tanzania. According to the 1998 mining Act and the 1999 Land Act, entails that all land in Tanzania is formerly owned by the state and that any relocation practice, must adhere to the stipulated provisions. However, forced relocation has remained highly contested issue since many people lack formal rights to the land from which they are displaced (Lange, 2011; Kabote \& Niboye, 2013).

One effect of this has been to exacerbate tensions between the large-scale and small-scale sectors, resulting in conflict over land and other key livelihood resources. The need has therefore arisen to formalize the ASM sector, including through registering and organizing unregulated mining, bringing ASM into the formal economy. Furthermore, while large scale mining; artisanal and small scale mining is the two sub-sectors covered in the policy, the artisanal and small scale mining sub-sector is being excluded in most cases. In light of this, although the policy environment in the sector does not sufficiently addresses the needs of all actors in the sector, there some opportunities Tanzania can exploit to ensure that the sector becomes beneficial to all actors sustainably.

\subsection{The Experience of the Regulatory Environment in Other Contexts}

In the context of Africa, most of these countries are dependent on mineral resources (Fessehaie \& Rustomjee, 2018; Fessehaie et al., 2016). While most of these countries have shown disappointing results with respect to sustainable use of resources, experience in other resource rich countries such as Botswana has shown that the mining sector can be turned into broader socio-economic development. According to Komba et al. (2018) some of the important factors underlying successful experiences in any investment include effective policy frameworks and implementation institutions. In Botswana for example, the mining policy has been characterized by remarkably ambitious goals, coherent design and effective implementation. While this is a better experience with respect to such countries, the situation is contrary to the Tanzania context where the mining sector has been associated with disappointing results.

In Mozambique, as the size of the extractive industry expanded, the country have been involved in strengthening the legal frameworks and fiscal regimes for the mining sector by increasing transparency in operations and reporting. For example, in 2009, Mozambique applied to the extractive industry transparency initiative and was declared fully compliant with EITI rules in 2012 with its second report covering 2010. Mozambique also endorsed the Global Partnership for Social Accountability in 2012, which aimed to improve development results by supporting enhanced citizen participation and feedback (Clement and Peiris, 2008). As a result, Mozambique has been one among the fastest growing economies in Sub Saharan Africa over the last 20 years, with an average of annual real Gross Domestic Product (GDP) growth of 7.4\% (World Bank, 2009). This strong performance was aided by the determined implementation of credible macroeconomic policies and structural reforms, a favourable external environment, donor support and in recent years, the discovery and exploitation of natural resources. In this regard, Mozambique have been performing better on governance with improvement in key areas such as government effectiveness, regulatory quality and the rule of law (World Bank, 2009).

In Namibia, her constitution requires that all natural resources belong to the state. The mineral prospecting and mining Act of 1992 provides that all rights and control over minerals rest with the state (Global Witness, 2010). The Namibian government has developed its mineral policy to ensure development of the mining industry. The policy is designed to attract both foreign and local investment in mining. The policy also seeks to provide opportunities for the Namibian people so that they benefit from their country's mineral resources in line with the government's policy of improving socio-economic conditions for all citizens (Dougherty, 2011; Global Witness, 2010).

It is generally said that Namibia's policy document is remarkably clear in its intent and it allows for greater state participation in mining production to secure direct benefit from mineral production for Namibians. As a result, Namibian mining sector performance has been impressive recording a GDP share of $12 \%$ from mining by the year 2012. The situation in other countries such as Botswana, Ghana and Zambia where the sector has been performing well, local content policies are developed and implemented with the objective of capturing more benefits from the sector (Nwape, 2016; Wilcox, 2015; World Bank, 2009). Due to the potential benefits accrued by local people, it has been necessary for countries rich in mineral resources to include local content provisions in their policies and laws as the case in Tanzania. There is therefore a need to improve this situation because 
participation of local citizens in the sector's activities is important for the integration into local economies and hence for poverty reduction. In the Tanzanian situation, the contribution of mining to the Gross Domestic Product (GDP) is still low when compared to Namibia and Botswana. However, such contribution has slightly increased from $3.7 \%$ in 2014 to $4.0 \%$ in 2015 and $4.8 \%$ in 2016, respectively (BOT, 2017). In this regard, Namibia and Botswana are regarded as role models for Sub-Saharan African Countries as they have expanded their economic development by strengthening their mining sectors (Collier \& Hoffler, 2002).

Furthermore, experience in countries such as Australia shows that, local content policies in the mining sector are defined at the national as well as at the state level (Nickers \& James, 2017). The key principle in Australian policies is to offer full, fair and reasonable access to employment and tendering opportunities to Australian firms and individuals. Alongside this is a relatively soft requirement for firms to implement the requirements. In all these cases, there is a strong reporting requirement on the measures taken to recruit and procure locally. Together with this, the monitoring, component of Australia's policies is also considered essential to ensuring public accountability.

\subsection{The Lessons Drawn from Other Contexts in the Mining Sector}

The discoveries of the country's resource deposits, especially natural gas, have the potential to significantly contribute to the economic growth and development thereby supporting the diversification of the economy into high value adding activities and thus, improve the living standards of citizens in Tanzania. However, this has been a challenge for quite some time in terms of realizing this potential partly due to weak linkages between mining activities and the local economies. It is equally revealed that the weaknesses reflected in the regulatory environment contribute greatly to the minimal contribution of the sector to the economy and wellbeing of the community (Kahyarara, 2015; Muganyizi, 2012; Lugoe, 2012).

In view of the above, Tanzania has an opportunity to learn from the experience drawn from other successful countries by embracing on effective application of regulatory framework and institutional capacities to ensure that there is coordination towards enforcement and maintain coherence with other sectoral policies. This analysis validates the thesis that resource based growth is possible through development of requisite skills, increasing domestic technological capabilities, appropriate designed and implemented policies and strong institutional capabilities. In this regard, successful countries in the context of the mining sector have shared features. They all have well-established mining sectors and in all these contexts, policies have played a critical role in opening up or closing down the opportunities for resource based growth and inclusive development. Additionally, the respective governments have played a key role in fostering development linkages with the mining industry.

Viewed in the context of Tanzania, this suggests that there is an important role for the government in the development trajectory of resource rich countries. When this task is left to the market forces alone, these linkages industries may not take off or may take off with limited value addition. Tanzania can also learn that when well-managed, the mining sector can create jobs, stimulate the transfer of technologies and knowledge and generate valuable foreign exchange earnings, thus provide governments a financial base for the development of infrastructure and the provision of social services. This paper demonstrates therefore that the success or failure of a resource based growth and development is country specific. This depends on the establishments of appropriate policy instruments.

\section{Conclusions and Recommendations}

\subsection{Conclusions}

This paper has analyzed the opportunities and challenges with respect to the policy environment of the mining sector in Tanzania. The findings show that Tanzania's mining sector undergone major reforms, which were geared towards the achievement of sustainable management of the sector. Based on the discussion made in this review, the main findings of this paper show that although the existing mining regulations address many of the stipulated policy objectives, in practice however, there are a number of key issues that should be addressed to ensure that there is a well-functioning regulatory environment of the mining sector in Tanzania. This will be made possible when aligned with measures to improve the policy framework which is particularly needed in areas where the policy gaps have allowed for the persistence of poor practices.

Moreover, development of a comprehensive approach to formalize the sector and in particular, to improve artisanal and small-scale miners with a view to enhance its importance will contribute to enhance local livelihoods since its impacts are more felt at the local level. This may be possible through deliberate efforts to improve the participation of various stakeholders including the local people. In turn, this will enhance transparence and accountability in the sector thereby making mining companies accountable not only to the 
government but also to the general public. On that basis, it is important for policy and legal reformist to pay more attention to the voices of the public which are increasingly demanding inclusion in policy processes that enhances equitable distribution of mineral resources. This will require an existence of the policy enabling environment coupled with strong institutions that effectively enforces the regulations. It will also mean to ensure that the interests of all actors in the sector are accommodated.

\subsection{Recommendations}

Informed by various experiences from other context and practices in the mining sector in different parts of the world, the following recommendations are made from this review;

Since the application of an effective regulatory framework has proved success in countries where mining has contributed to sustainable development, the government should improve the existing regulatory framework to enhance transparency and accountability in the management of mineral resources as reflected in the lessons from other successful countries in the sector.

Since the realization of the sector's potential depends on large part on Tanzania's ability to design good policies and implement them effectively, one of important component of the policy framework is local content strategy. The paper recommends that the government should design clearly defined regulatory and institutional framework with effective implementation and enforcement of laws and regulations for local content compliance in the mining sector.

Public access to information has proved success in resources management in countries where mining has contributed significantly to sustainable development and that the existing framework has limited explicitly transparency provisions, this death of information prevents the public from knowing what requirements have been imposed on companies on land acquisition and resettlements issues, this paper recommends that the government in collaboration with other stakeholders should design an efficient legal framework which is monitored and transparent that accommodates the interests of all actors to guide the land acquisition and resettlements processes in the mining sector.

Formalizing the ASM sub sector in the context of an effective regulatory framework has proved success in countries where ASM has contributed to sustainable development for the majority, this paper recommends that the government should design clearly defined legal framework with effective implementation and enforcement of laws and regulations geared towards formalizing the sub sector.

In all cases, the issue of compliance of companies to the regulatory framework is pertinent to the success of the mining sector. However, this was beyond the scope of this paper. In this view, this paper recommends further studies to look at the aspects of compliances to the regulatory framework in the mining sector.

\section{Acknowledgments}

First and foremost, we would like to express our sincere thanks to the Mwalimu Nyerere Memorial Academy's management for the financial support given and permission to pursue $\mathrm{PhD}$ studies. We would like also to genuinely thank Sokoine University of Agriculture for granting research permit to undertake this study successfully.

\section{References}

Acuna, R. M. (2015). The politics of extractive governance: indigenous peoples and social- environmental conflicts. The Extractives Industries and Society, 2(1), 85-92. https://doi.org/10.1016/j.exis.2014.11.007

African Development Bank Group. (2012). Gold Mining in Africa: Maximizing Economic Returns for Countries. Working Paper Series No. 147.

Akabzaa, T. (2009). Mining in Ghana: Implications for national economic development and poverty reduction. In C. Bonnie (Eds.), Mining in Africa: Regulation and Development (pp. 25-65). Pluto Press, New York.

Andrews, N., \& Nwapi, C. (2018). 'Bringing the State Back in Again? The emerging developmental State in Africa's Energy Sector. Energy Research and Social Science, 41, 48-58. https://doi.org/10.1016/j.erss.2018.04.004

Ange, K. A. (2014). Challenges and Prospects of Equitable Benefits Sharing in Mining Sector: A case Study of Titanium Mining in Kwale Country, Kenya. Dissertation for Award of MSc Degree at University of Nairobi, Kenya.

Auty, R. M. (1993). Sustaining Development in Mineral Economies: The Resource Curse Thesis. London: Routledge. https://doi.org/10.4324/9780203422595 
Bengesi, K. M. K. (2014). Assessing Impact of Biofuel Investments on Local Livelihoods in Tanzania: A case of Kisarawe, Bagamoyo and Kilwa Districts. Retrieved October 15, 2018, from http://www.mviwata.org/wp-content/uploads/2014/09/Study-Report-on-Biofuel-Investments-July2012.pdf

Bengesi, K. M. K. (2018). Investment Incentives and Dilemma of Local Investors for Agricultural Development in Tanzania: Do Policy Makers Talk the Same Language to Local Investors? Paper presented During Policy Seminar Series Forum at Sokoine University of Agriculture, 13 February 2018 (Unpublished).

Bengesi, K. M. K., Msuya, C. P., Salanga, R., \& Mwakalobo, S. (2009). Implication of Biofuel Production on Food Security in Tanzania. Retrieved May 2, 2018, from http://www.actionaid.org/sites/files/actionaid/implication_of_biofuels_production_on_food_security_in_tan zania.pdf

Besada, H., \& Martin, P. (2015).Mining codes in Africa: emergence of a 'fourth' generation? Cambridge Review of International Affairs, 28(2), 263-282. https://doi.org/10.1080/09557571.2013.840823

Besanda, H., \& Martin, P. (2013). Mining Codes in Africa: Emergence of a "Fourth" Generation?

BOT. (2017a). Economic Bulletin for the Quarter Ending September, 2017 409. Retrieved May 21, 2017, from http://www.bot.go.tz

BOT. (2017b). Tanzania Investment Report 2014: Bank of Tanzania, Dar es Salaam. Retrieved June 4, 2017, from https://www.bot.go.tz

Botswana Institute for Development Policy Analysis. (2011). Study to Map Investment Opportunities in District and Town Councils in Botswana. Botswana Institute for Development Policy Analysis, Gaborone, 59(1), $1-89$.

Bryan, S., \& Hofmann, B. (2007). Transparency and Accountability in Africa's Extractive Industries: The Role of the Legislature. Printed in the United States of America.

Burton, E. G. (2014). Reverse the Curse: Creating a Framework to Mitigate the Resource Curse and Promote Human Rights in Mineral Extraction Industries in Africa.

Campbell, B. (2006). Good governance, security and mining in Africa. Minerals and Energy, Raw Materials Journal Minerals \& Energy - Raw Materials Report, 21(1), 31-34. https://doi.org/10.1080/14041040600575813

Campbell, B. (2007). Better resource governance in Africa: on what development agenda? Journal Minerals and Energy, Raw Materials, 21(4), 3-18.

Campbell, B. (2010). Revisiting the reform process of African mining regimes. Canadian Journal of Development Studies, 30(2), 197-217. https://doi.org/10.1080/02255189.2010.9669288

Clément, J. A. P., \& Peiris, S. J. (2008). Sustaining Growth Take-offs: Lessons from Mozambique. In J. A. P. Clément, \& J. S. Peiris (Eds.), Post-Stabilization Economics in Sub-Saharan Africa: Lessons from Mozambique (pp. 12-81). International Monetary Fund, Washington.

Collier, P., \& Hoeffler, A. (2002). On the Incidence of Civil War in Africa. Journal of conflict Resolution, 46(1), 13-28. https://doi.org/10.1177/0022002702046001002

Curtis, M., \& Ngowi, H. P. (2017). The One Billion Dollar Question: How Much is Tanzania Now Losing in Potential Tax Revenues? Jamana Printers. Dar es Salaam,Tanzania Episcopal Conference, National Muslim Council of Tanzania and Christian Council of Tanzania, Dar es Salaam. p 62pp.

Dansereau, S. (2005).Win-win or new imperialism? Public-private partnerships in Africa mining. Review of African Political Economy, 32(103), 47-62. https://doi.org/10.1080/03056240500121024

Dansereau, S. (2010). Comparing dueling approaches to the transformation of South African mining: Corporate social responsibility or labour restructuring? Labour, Capital and Society, 43(1), 63-98.

Darimani, A., Akabzaa, T. M., \& Attuuayefio, D. K. (2013). Effective environmental governance and outcomes for gold mining in Obuasi and Birimi North Districts of Ghana. Miner Economics, 14(26), 47-60. https://doi.org/10.1007/s13563-013-0036-2

Dougherty, M. L. (2011). A Policy Framework for New Mineral Economies: Lessons from Botswana, Illinois State University. Retrieved June 1, 2016, from http://www.uvm.edu/ieds/sites/default/files/Botswana_Minerals.pdf

Elbra, A. (2014). Gold mining in Sub-Saharan Africa: towards private sector governance. The Extractive 
Industries and Societies, 1(2), 216-224. https://doi.org/10.1016/j.exis.2014.07.008

Fessehaie, J., \& Rustomjee, Z. (2018). Resource based industrialization in South Africa: Domestic Policies, Corporate Strategies and Regional Dynamics. https://doi.org/10.1080/0376835x.2018.1464901

Fessehaie, J., Rustomjee, Z., \& Kaziboki, L. (2016). Can Mining Promote Industrialization? A comparative Analysis of Policy Frameworks in Three Southern African Countries. United Nations University, UN-WIDER Working Paper 2016/8, World Institute for Development Economics Research. https://doi.org/10.2139/ssrn.2923059

Frynas, J. G. (2005). The false development promise of corporate social responsibility: Evidence from multinational oil companies. International Affairs, 81(3), 581-598. https://doi.org/10.1111/j.1468-2346.2005.00470.x

Global Witness. (2010). Return of the Blood Diamond:the deadly race to control Zimbabwe's New-Found Diamond Wealth. Retrieved April 26, 2018, from https://www.globalwitness.org/.../

Hilson, G., \& Roy, M. (2009). Good governance and the extractive industries in Sub-Saharan Africa. Mineral Processing and Extractive Metallurgic Review, 30, 52-100. https://doi.org/10.1080/08827500802045511

International Council on Mining and Metals. (2014). Enhancing Mining's Contribution to the Zambian Economy and Society. Chamber of Mines of Zambia, Zambia.

International Council on Mining and Metals. (ICMM, 2012). Human Rights, Social Development and the Mining and Metals Industry, London.

Jaiswal, S. (2017). Foreign Direct Investment in India and Role of Tax Havens. Centre for Budget and Governance Accountability, New Delh, India. Retrieved June 21, 2017, from www.cbgaindia.org

James, S. (2010). Providing Incentives for Investment: Advice for Policy Makers in Developing Countries. Investment Climate in Practice, The World Bank Group, USA.

Jeschke, M. (2010). Extractive Industries Review. In Visser W., Matten D., Pohl M., \& Tohurst N. (Eds.), The A to $Z$ of corporate social responsibility (pp. 25-27). Hoboken: John Wiley \& Sons Ltd.

Kabange, N. J. (2013). Improving the Governance of Mineral Resources in Africa through a Fundamental Based Rights Approach to Community Participation: Thesis Submitted in Accordance with the Requirements for the Degree of Doctor of Laws at the University of South Africa.

Kabote, S. J., \& Niboye, E. P. (2013). Socio-economic effects of large scale gold mining on artisanal miners in Tanzania: Experiences from Bulyanhulu Gold Fields: A Paper Presented at Research on Poverty Alleviation 18th Annual Research Workshop Held at the Kunduchi Beach Hotel, Dar es Salaam, Tanzania, 3-4 April, 2013. pp. 1-62.

Kahyarara, G. (2015). Review of Governance and Development of Mining Sector in Tanzania: A Paper Presented at Research and Poverty Alleviation 20th Annual Research Workshop held at the Ledger. Plaza Bahari Beach Hotel, Dar es Salam, Tanzania. 25-26 March 2015. pp. 1-46.

Kinda, T. (2010). Investment Climate and Foreign Direct Investment in Developing Countries: Firm Level Evidence. World Development, 38(4), 498-513. https://doi.org/10.1016/j.worlddev.2009.12.001

Kitula, A. G. N. (2006). The environmental and socio-economic impacts of mining on local livelihoods in Tanzania: A case study of Geita District. Journal of Cleaner Production, 14, 405-414. https://doi.org/10.1016/j.jclepro.2004.01.012

Komba, A.M; Bengesi, K.M.K and Mwageni, T. (2018). Planning: Concept, Theories and Models, In Lifuliro, C., Zilihona, I., Mdendemi, T., Kamanzi, A., Kinyashi, G. \& van Djik, T (eds.), Tanzania Planners' Handbook: A guide for Development Planning. African Studies Center, Leiden, Netherlands. Pp.31-41.

Kronenberg, T. (2004). The Curse of Natural Resources in the Transition Economies. Economics of Transition, 12(3), 399-426. https://doi.org/10.1111/j.0967-0750.2004.00187.x

Lange, S. (2011). Gold and Governance: Legal Injustices and Lost Opportunities in Tanzania. African Affairs, 110(439), 233-252. https://doi.org/10.1093/afraf/adr003

Lange, S., \& Kinyondo, A. (2016). Resource Nationalism and Local Content in Tanzania: Experiences from Mining and Consequences for the Petroleum Sector. The Extractive Industries and Society, 3(40), 1095-1104. https://doi.org/10.1016/j.exis.2016.09.006

Lederman, \& Maloney. (2007). Natural Resource neither curse nor Destiny, the World Bank, Stanford University 
Press, Washington; DC p.396.

Leveille, E. (2009). Natural resources: Unavoidable curse or manageable asset? Journal of Politics \& International Affairs, 6(7), 108-125.

Lissu, T., \& Curtis, M. (2008). A Golden Opportunity? How Tanzania is Failing to Benefit From Gold Mining. Christian Council of Tanzania, National Council of Muslims in Tanzania and Tanzania Episcopal Conference, Dar es Salaam.

Lugoe, F. (2011). Aligning and harmonizing the livestock and land policies of Tanzania. Retrieved November 13, 2017, from www.esrftz.org

Lugoe, F. (2012). Governance in Mining Areas in Tanzania with Special Reference to Land issue. The Economic and social Research Foundation (ESRF), Discussion Paper No 4 DSM Tanzania.

Magai, P., \& Marquez, V. (2011). Tanzania's Mining Sector and its Implications for the Country's Development. DAAD Partnership. Retrieved January 21, 2018, from http://hdl.handle.net/20.500.11810/4287

Maliganya, W., \& Renatus, P. (2017). The Impact of Large Scale Mining on the Livelihoods of Adjacent Communities: The Case of Geita Gold Mine, Tanzania. Research on Poverty Alleviation (REPOA), Dar es Salaam, Tanzania.

Malunga, G., \& Phalira, W. (2015). Assessment of Mining Policy Implementation in Malawi. Centre for Environmental Policy and Advocacy, Malawi.

Mbowe, W., Yabu, N., \& Lugobi, M. (2016). Tanzanite Processing in Tanzania: Challenges and Opportunities. Bank of Tanzania Working Paper Series No. 9, Bank of Tanzania, Dar es Salaam. https://doi.org/10.11114/aef.v3i3.1640

Mikesell, R. F. (1997). Explaining the resource curse, with special reference to mineral exporting countries. Resources Policy, 23(4), 191-199. https://doi.org/10.1016/S0301-4207(97)00036-6

Mpelumbe, D. G. (2012). Multinational Mining Corporations, State Regulation and Human Rights Protection in Tanzania: Invoking Command and Control Instruments towards Effective Corporate Social Responsibility. University of Tromso.

Muganyizi, T. K. (2012). Mining Sector Taxation in Tanzania. International Centre for Tax and Development. UKaid and NORAD, Institute of Development Studies, UK. https://doi.org/10.2139/ssrn.2436459

Mwakaje, A. G. (2013). Assessing the Contribution of Environmental Impact Assessments in Informing Decision Makers Concerning the Booming of FDI in Tanzania. Journal of Environment and Natural Resources Research, 3(4). https://doi.org/10.5539/enrr.v3n4p118

National Bureau of Statistics. (2011). Tanzania Demographic and Health Survey 2010. ICF Macro Calverton, Maryland, USA.

National Democratic Institute for International Affairs, USA.

Ndulo, M. (2013). Legal and Regulatory Frameworks for Resource Exploitation and Extraction-Global Experience. Cornell University's Institute for African Development, Maputo, Mozambique.

Nwapi, C. (2016). A Survey of the Literature on Local Content Policies in the Oil and Gas Industry in East Africa. The School of Public Policy, University of Calgary.

Pedro, A. (2012). The Africa Mining vision: Towards shared benefits and economic transformation. Great Insights, 1, 1-5.

Poncian, J., \& George, C. (2015). Mineral Extraction for Socio-Economic Transformation of Tanzania: The need to move from papers to implementation of mining policy and law. Journal of Social Science Studies, 2(2), 2329-9150. https://doi.org/10.5296/jsss.v2i2.7450

Rutaihwa, J., \& Simwela, A. (2012). Econometric Analysis of FDI in the Mining Sector to Tanzania's Export Capacity. International Journal of Academic Research in Business and Social Sciences, 2(10), 174-191.

Shivji, I. G. (2007). Bloody Gold on My Land, Saturday Palaver, The Citizen, Dar es Salaam, 13 October.

UNCTAD. (2014). Economic Development in Africa: catalyzing investments for transformative growth in Africa. Report. United Nations Conference on Trade and Development UNCTAD, New York, USA.

UNESCO. (2009). Africa Review Report on Mining. It Talks More on Effective and Transparent Regulatory Frameworks and on How to Effectively Handle Environmental, Economic, and Social And Health Impacts. 
Economic Commission for Africa, Addis Ababa, Ethiopia.

United Republic of Tanzania. (1997). The National Environmental Policy. Vice President's Office, Dar es Salaam, Tanzania.

United Republic of Tanzania. (2008). Presidential Mining Review Committee to Advise the Government on Oversight of the Mining Sector, Translated from Kiswahili to English by Paperwork Associates Tanzania on Behalf of Policy Forum. Government Printers, Dar es Salaam.

United Republic of Tanzania. (2009). The Mineral Policy of Tanzania. Ministry of Energy and Minerals, Dar es Salaam, Tanzania.

United Republic of Tanzania. (2010). The Mining Act of Tanzania. Ministry of Energy and Minerals, Dar es Salaam, Tanzania.

United Republic of Tanzania. (2011). National Strategy for Growth and Reduction of Poverty II. Ministry of Finance and Economic Affairs, Dar es Salaam.

United Republic of Tanzania. (2012). MKUKUTA National Strategy for Growth and Reduction of Poverty, Poverty and Human Development Report 2011. Ministry of Finance and Economic Affairs, Dar es Salaam.

United Republic of Tanzania. (2012). Poverty and Human Development Report 2011. Research and Analysis Working Group, Ministry of Finance, Dar es Salaam, Tanzania.

United Republic of Tanzania. (2013). The National Natural Gas Policy of Tanzania. Ministry of Energy and Minerals, Dar es Salaam.

White, S. (2017). Regulating for Local Content: Limitation of Legal and Regulatory Instruments in Promoting Small-Scale Suppliers in Extractive Industries in Developing Economies. The Extractive Industries and Society, 4(2), 260-266. https://doi.org/10.1016/j.exis.2016.08.003

Wilcox, J. (2015). Mining Regulation and Development in Botswana: The Case of the Debswana Mining Joint Venture. Dissertation for Award of MSc Degree at Saint Mary's University, Halifax, Nova Scotia.

World Bank. (2009). Albania Mining Sector Reform, Restructuring and Future Prospects. Oil, Gas and Mining Division, Europe and Central Asia Region. World Bank, Washington DC.

Zee, H. H., Stotsky, J. G., \& Ley, E. (2002). Tax Incentives for Business Investment: A primer for policy makers in Developing Countries. World Development, 30(9), 1497-1516. https://doi.org/10.1016/S0305-750X(02)00050-5

\section{Copyrights}

Copyright for this articleis retained by the author(s), with first publication rights granted to the journal.

This is an open-access article distributed under the terms and conditions of the CreativeCommons Attribution license (http://creativecommons.org/licenses/by/4.0/). 